\title{
L'homme agissant and Self-understanding: Pamela Sue Anderson on Capability and Vulnerability
}

\section{ABSTRACT}

This article addresses Pamela Sue Anderson's philosophy of capability and vulnerability as an important contribution to the advancement of today's feminist ethics. Following Paul Ricœur's hermeneutics of l'homme capable, Anderson extends the phenomenological perspective of the capable human subject to embrace the distinctly feminine capability. She advocates for women's recognizing and re-inventing of themselves as capable subjects, and claims that the perturbing initial loss of confidence in their reflective capacities can be redeemed via the transformations in women's emotional and religious lives, as well as through their creative impulse. Locating in hermeneutics' openness to ambiguity, incompleteness and insecurity a potential to unveil the non-transparent aspects of the assumed malefemale equality, Anderson focuses on the interlocking aspect of human capability and vulnerability. She calls for transforming an ignorance of vulnerability into an ethical avowal of it. In reconfiguring patriarchal culture myths, Anderson sees the possibility of re-shaping our approach to vulnerability and capability, especially the human capacity for love.

Keywords: capability, self-understanding, Pamela Sue Anderson, Paul Ricœur, vulnerability. 


\section{INTRODUCTION}

In her reflection on the pre-given capable subject, Pamela Sue Anderson takes as a point of departure Paul Ricœur's hermeneutics of l'bomme capable (see especially Oneself as Another [1990] and The Course of Recognition [2004]). In hermeneutics' openness to various and also conflicting interpretations, Anderson sees a chance to give a fuller account of human capability. She argues for hermeneutics' propensity to create a spacious perspective for an understanding of the human subject in her/ his gendered aspect and recognizes phenomenological investigation's insufficiency in this respect. Anderson's personal history-the Lutheran upbringing and the feeling of an important part of her self as constrained ("Engaging" 314) —urges her to search for a retrieval of the specifically feminine capability, which she recognizes as lost. She rests her thinking on a critique of Western culture myths and is especially concerned with the meaning and impact of the Biblical story of Adam and Eve. In her endeavor to restore feminine capability, Anderson uses Julia Kristeva's and Luce Irigaray's feminist writings (cf. Anderson, "Engaging” 320), although she does not follow their psycholinguistic path that acknowledges the implications of the human subject as sexually differing.

\section{THE LOSS OF CONFIDENCE, RECOGNITION AND SELF-REFLEXIVITY}

Anderson's philosophical deliberation on human capability, driven by an acute sense of loss, the loss of something she discerns to be a uniquely feminine confidence of being a capable subject, is consequential for the development of her feminist philosophy of religion. Setting herself the task of probing the problematic of this loss with the available feminist apparatus, she draws on Simone de Beauvoir and Judith Butler, as well as the already mentioned Kristeva, and Irigaray. Investigating female philosophy as that which is in the shadow of male philosophy, she reflects on the womanphilosopher's starting point ("the primal scene" as identified by her friend, French feminist philosopher Michèle Le Dœuff)—the experience of initially being banned from philosophy (Anderson, "Primal Scene" 13). The event of being excluded is emblematic of the feminine experience of the masculine world of philosophy. The prohibition/marginalization of the distinctively womanly capability reverberates strongly in the female subject's mind, incapacitating her from thinking positively about her reflective aptitude. Anderson draws on Le Dœuff's recollection of her teacher's words, at once condescending and attesting to his own intellectual ineffectuality: "That is much too hard for you. Kant . . . Kant ... you 
know ... Kant is very difficult ... (143-44; emphasis added)" ("Primal Scene" 13-14). Feminine capability needs to be voiced, to gain in power, or, rather, to regain its original strength. This voicing is the empowerment of thinking, of thinking-the-difference, of recognizing other thinking in its differing texture. Baffled by the ban, the female capability seeks ways to overcome the constraint, to display a woman's own inimitable ways of cultivating reflectivity. This expositional move to transgress the barrier of "the forbidden" stumbles against the simultaneous introvert countermove of "shying away" because of not being recognized by the male Other.

The question of recognition is pivotal in an understanding of the female need to reclaim her true self, while she is disengaging herself from the masculine bias and mistrust of her capacity of reflectivity. Paul Ricœur's The Course of Recognition (2004) is helpful in locating the meaning of the recognition of oneself, the Other, and of mutual recognition, which happen on an interpersonal and societal level. For the sake of elucidating the loss of confidence in the feminine subject we shall extend this perspective and refer to thinkers whose intuitions are complementary to Ricœur's, while introducing at the same time a slightly different angle of vision. Mutual approbation of the entirety of the Other's existence is the staple condition of recognition's indispensability in the even distribution of the epistemic power between male and female subjects. In her essay on personal identity construction, Gabriele Chiari, demonstrating the proximity of Ricœur's, Axel Honneth's and William James's thinking, provides us with an important insight into the problematic of recognition. She convinces us that mutual recognition is the only pathway to mature intersubjectivity_- "an intersubjective balance between emotional fusion and ego-demarcation” (59). Whereas Honneth stresses disrespect as the basic source of the loss of confidence, Ricœur takes his point further, speaking of the lack of approbation that can be equated with a feeling of non-existence: "The individual feels looked down on from above, even taken as insignificant. Deprived of approbation, the person is as if nonexistent" (Ricœur, Course of Recognition 191). In a similar vein, James accentuates the exigency of recognition for the subject's psychological stability and a sense of existence (Chiari 61). Recognizing oneself as a capable self and being recognized by the Other as capable originates and facilitates our self-understanding (Selbstverständnis) - gaining practical knowledge of the laudable position of being a human being, recognizing one's strengths and weaknesses. Identification of the lack of approbation, as well as the areas of psychological destabilizations as painful wounds inflicted by a male subject helps deconstruct a woman's loss of confidence and construct it anew in an arduous process of rebuilding her feminine capability.

The initial, underprivileged position experienced by a female subject is the source of a righteous resistance and calls for renunciation. 
Recognition of the Other is not possible when the approbation of her/him is negated. The feminine unarticulated, silenced or ignored voice searches for its gendered and legitimate locatedness. Ever since the moment of recognition of not-being-recognized, the diverse faces of the feminist philosophical project can be nailed down to the varied forms of combating the poignant imbalance between sexes in terms of their self-reflective potential. The capable female subject wrestles to redeem the primordial harmony of human capacity, expressed in the Latin formula of homo capax Dei. Impacted by Ricœur's hermeneutics of l'bomme agissant, Anderson attempts to rehabilitate feminine capability by bringing it back to its primal source-the creation of a human being in God's likeness. It is instructive to mention at this point the backdrop of Ricœur's philosophy of l'bomme capable-its two important sources. Through Gabriel Marcel, Ricœur delves into the repository of the Christian tradition of a human being's privileged position in the universe as a person able to love and know God. The other important source for him is the Protestant notion of a human being, with a special reference to Karl Barth and his formula of finitum non capax infiniti, which accentuates the insurmountable distance between the human and the divine (cf. Wiercinski, Hermeneutics of Education 141).

To delve deeper into the salient truth of a human being as homo capax Dei, we will use John Crosby's splendid explication of it in his book The Personalism of John Henry Nerwman, where he reminds us of the interrelatedness of human capability and the infiniteness of God's capacity:

In a living relation to God, if only in the form of yearning for God, we experience ourselves as capax Dei, as having a capacity for God, as therefore having an infinite capacity, an infinite abyss of existence. Without this relation to God we would not know ourselves, would never suspect our infinite capacity, and so we would underestimate ourselves, and would remain vulnerable to being intimidated by the immensity of space-time, and to being depersonalized. (163)

To understand Anderson's venture to recuperate feminine capability in the light of Ricœur's recourse to the Christian tradition of bomo capax $D e i$ is of no small significance. The original equity of the male and female subjects is entrenched in God's bestowing dignity on the two sexes and making them equally capable. Thus, we are not "mere cosmic specks" (Crosby 163), but are driven by an enormous power-via a recognition of the divine in us, we are capable of experiencing the restless and unlimited possibilities that we are. Anderson's feminist philosophy of religion, when situated within a wider context of phenomenological and hermeneutic inquiry, allows the admirable position of a female subject, and her equal propensity for creativity and self-reflectivity, to be seen. Anderson's re- 
visitations of Ricœur's hermeneutics of the self remind us of his germane words: "The confidence I place in my power to act is part of this very power. To believe that I can is already to be capable" (Ricœur, "Autonomy and Vulnerability" 76). The increase in power is meaningfully evocative of Gadamer's notion of an increase in being (Zuwachs an Sein) (see Gadamer 135-36). Applicable to the subject's empowerment, the placing of confidence in one's power results in being empowered, and thus in an increase in being.

Anderson criticizes the assumed gender-neutrality in Western philosophy which camouflages the actual inequality in the acknowledgement of the epistemic power of female and male subjects, stating the following:

Claims to gender-neutrality in Western philosophy conceal highly significant issues of loss of confidence, loss of epistemic justice and loss of reflexive self-understanding. Loss not only damages subjects of knowledge and action, but this damage obscures that which was in phenomenological terms originally given: capability. ("Lost Confidence" 43)

Re-addressing Ricœur's hermeneutic phenomenology, Anderson recognizes the strengths of the phenomenological investigation, while seeing in hermeneutics further possibilities to inquire into the nontransparent aspects of the supposed male-female equity.

\section{HERMENEUTIC SENSIBILITY AND THE QUESTION OF HUMAN CAPABILITY}

Hermeneutics welcomes the ambiguous, the incomplete, the insecure, and thus it grants us with a true possibility to reach the otherwise inaccessible and nuanced senses of the problematic at hand. Anderson credits hermeneutic interrogation in its special propensity for unraveling the abstruse and the confusable thus:

Hermeneutics is interpretation; and, in this context, the hermeneuticist interprets the opaque, in order to make the capacities of the subject more transparent. So, hermeneutics can help women and men to make sense of themselves, to understand their own cognitive and conative abilities, and to achieve greater self-awareness. ("Lost Confidence" 43)

In displaying its hospitable gesture, hermeneutics situates itself in the position of recognizing and listening to the voices whose expression was counteracted and disavowed. Hermeneutic sensibility's all-embracing horizon is the space of the limitless possibilities of interpretation. In 
recognizing the dignity of opposing interpretations, hermeneutics precludes violence, oppression and calculation (cf. Wierciński, Existentia Hermenentica 387). Pursuing her project to reinstate the validity of the blocked, or even hideously subjugated, feminine voice, Anderson locates her endeavor at the very heart of hermeneutic investigation. It is worth highlighting once again that hermeneutics is "in the service of those voices that are suppressed and denied expression" (Wierciński, Existentia Hermeneutica 387).

Concerned with the silencing of the feminine voice, Anderson aims to heighten awareness of the gendering of philosophy in the changing landscape of European culture. At the same time, she calls for our openness to philosophy's possibility to "articulate the material, social and cognitive dimensions of a subject's conditioning," and emphasizes hermeneutics distinctive role in locating and explicating those dimensions of our humanness which are opaque and phenomenologically understood as "nonnatural" ( "Lost Confidence" 43). Her employment of Ricœur's thinking to elucidate the subject's conditioning involves yet another important perspective - an understanding of a human person as an embodied subject. Alongside Husserl, Martin Heidegger, Gabriel Marcel, Maine de Biran, Merleau-Ponty and others, Ricœur endorses the conceptualization of human subjectivity as embodied (cf. Kearney 179-80). Ricœur maintains that the human subject is a body and also has a body that belongs to the world. According to him, it is exactly one's embodied being that is constitutive in discovering oneself as a capable human being. He writes:

\begin{abstract}
... in projecting myself as the subject of action, I affirm myself capable self of that action. To decide, we have said, is to project myself in general as the theme of conduct proposed for the body to obey. My capacity is hidden in the imputation of myself in the context of the project... I feel capable as an incarnate being situated in the world, of the action which I intend in general. (Ricour, Freedom and Nature 203)
\end{abstract}

The prescient content of the aforementioned quotation from Ricœur's early work Freedom and Nature: The Voluntary and the Involuntary (1950) interconnects with the subject matter of his influential Fallible Man (1960), Oneself as Another (1990) and The Course of Recognition (2004). Those works uphold three important theses in reference to human capability: the capable self is the embodied self, self-understanding is related to the conceptualization of the human subject as the embodied subject, and selfunderstanding is reflective rather than immediate. Ricœur's important insight into human capability as ensuing from the will entrenched in the embodied being can be summarized thus: "In spite of all conditioning, 
a human subject is not a subject-like object but a willing subject engaged in living being ... It is in this living, embodied existence that a subject finds him- or herself as capable" (Helenius 193). The embodied and reflective character of self-understanding, which Ricour propounds, seems to be crucial for an understanding of Anderson's reflection on the loss of, and the possibilities of regaining, a distinctly feminine capability.

Picking up on Ricœur's assertions, as well critiquing Merleau-Ponty's view of the body (in his Phenomenology of Perception) - the seeming openness of the "fleshy" existence as "located in a world it did not create and over which it does not have ultimate control"-Anderson makes a connection between the embodied subject and the female subject's loss of confidence in her capability ("Lost Confidence" 44). Upholding the stark binary opposition of body (the inferior - the feminine) and mind (the superior-the masculine), Western culture has proven to be a culture of denigrating the female subject-disturbingly viewing her as less capable. As Anderson argues, struggling to assert her voice, the female subject confronts the decapacitating configurations of woman's agency in myths, including religious myths.

Musing on the loss of female confidence evoked in the traditional patriarchal understanding of the Biblical story of Adam and Eve, she adds an example of the young de Beauvoir's loss of confidence. De Beauvoir upgrades the male capability of self-reflectivity when she thinks of Sartre "the philosopher," gives up her original thinking, and does not venture to call herself a philosopher (cf. Le Dœuff 136) (Anderson, "Lost Confidence" 44). In consequence de Beauvoir's self-doubt is expressive of the loss of her ability to understand herself and to think philosophically (Anderson, "Lost Confidence" 45). Combining Ricœur's hermeneutic phenomenology and de Beauvoir's existential phenomenology of "the second sex," Anderson sees "the bodily situation of a woman as originally capable, yet vulnerable to gender norms" ("Lost Confidence" 45). Gender-based vulnerability, as instantiated through de Beauvoir's case, inspires further interrogation of the question of lost confidence.

\section{ETHICS, L'HOMME CAPABLE AND L'HOMME FALLIBLE}

Before we tackle the problematic of vulnerability as enrooted in gender distinction, it is worth taking a closer look at a more general notion of vulnerability. Capability is intertwined with vulnerability. Human capacities and relatable vulnerabilities inform us about our condition of being human beings, both capable and liable to harm. Affected by the knowledge of his/ 
her strengths/gifts and the liability to get hurt, the self participates in an incessant quest for self-understanding, marked by a sense of provisionality, incompleteness and finitude. The essential relationship between capability and vulnerability can be viewed thus:

The fundamental capabilities/incapabilities of a human are linked with his/her corresponding vulnerabilities. As existing and inhabiting the world, the human person is, by virtue of the very nature of being human, also l'homme faillible. Human fallibility, weakness, and suffering describe the inabilities of the capable person. Ricœur's anthropology develops as the transition from the phenomenology of a suffering human being toward the phenomenological hermeneutics of the capable person. (Wierciński, Hermeneutics of Education 149)

It is our vulnerability which makes us open to love, friendship, justice, but also abuse, domination, injustice. Investigating various forms of oppressing and silencing women's voices, Anderson refers to the most basic notion of vulnerability as "being liable to wounding, to openness or exposure; this vulnerable relationality makes us liable to harm and infection, but also to mutual affection" ("Speaker Vulnerability"). This definition leads us to the potential source of gender-based vulnerability. The traditional, historically established, patriarchal distribution of power between genders encompasses women's position as more exposed to harm due to the social and financial dependence on men. This, however, is strictly related to a woman's self-esteem (governed by a male perspective) of emotional dependence, of being affectively bound to man. The fossilized schemes of dependence are often taken for love.

It is necessary to accentuate the possibility of the impairment of one's emotions by fear and anxiety in situations of vulnerability in love relations. Historically speaking, this has been an experience of women throughout centuries and appears in many forms in today's societies. The scarring of emotions relates to the incomprehensibility and misunderstanding in the case of an abuse of love, when, paradoxically and frightfully, instead of a fulfilling relation, one experiences an emotional mutilation, or a debasement of feelings. Deplorable as it is, the disgrace and disparagement of one's identity, total enslavement, or the taking away of part of one's freedom, which seems to be highly improbable in the case of love relations, does happen when attachment, compassion or duty are taken for love and the crux of love is misunderstood. Reflecting on human capabilities, Martha C. Nussbaum, the renowned contemporary social, political and feminist thinker, warns us: "Perception without responsibility is dangerously freefloating, even as duty without perception is blunt and blind" (155). In 
the tarnishing of love (when it is mistaken for duty or varied forms of emotional attachment), the shame brought on the Other, decapacitates and disables the self from loving truly. On the other hand, the loved one, if not loved genuinely, suffers from the corruption and the dishonor of not experiencing the authenticity of love. This results in acute humiliation and disablement, akin to that which happens in social situations-human capability is blemished.

The confusing journey of a feminine subject's self-discovery-her path toward self-understanding — can lead through a recognition of the depraved or constrained self as part of her self in order to regain her able self. Paradoxically, for the incapacitated female self, suffering displays a recuperative force of restoring inner balance, via combating the misgivings which shroud the pervasively poignant state of mental, emotional or physical inability, and haunt the positivity of self-search. Disabling can often mean denying one's freedom. It happens as something exterior, but it can arise from a self-denial in a situation of pressure, dominance and subordinance. The laborious path towards rehabilitation-the movement from an incapable to a capable self-rests on an increasing understanding of the available, the existing and the formerly undiscovered potentialities.

Despite being an uneasy path, the recourse to a genuine practicing of love becomes a remedy in the recuperation of human capability, and, at the same time, the restoration of the distinct feminine capability. Even though Anderson, in her essay "On the Boundaries of Intellectual Thought in Late Twentieth-Century Europe," is not explicit on the topic of capability and vulnerability, its concluding sentences say a lot about the exigency of love as the greatest of human capabilities. Ethically speaking, inasmuch as love makes us vulnerable, at the same time, it makes us capable. The renewing power of love partakes in the true refurbishing of the human subject as a capable subject. Anderson contends:

... we are aware that both individually and communally we need not only to discuss writings on exile and dissolution but to construct writings on love, that is to create those fragile boundaries that render concrete attachments possible. ... the urgent task for us on the boundaries of thought in late twentieth-century Europe is to learn to express love, calling ourselves to the ethical relationship in response to the Other.

("On the Boundaries" 49)

Since the issue of vulnerability as entwined with love is of special import in an interpretation of the common conceptualizations of vulnerability and vulnerable relationality, a closer look at some of the contributions to Love and Vulnerability: Reflections on the Work of 
Pamela Sue Anderson Conference, held at Oxford University between 16 and 18 March 2018, is instructive (see https://www.philosophy. ox.ac.uk/event/love-and-vulnerability-memory-pamela-sue-anderson). The participants paid homage to Anderson's momentous insights into the problematic of the human being as l'homme agissant and l'homme souffrant a year after her premature death. The speakers developed diverse "vulnerability paths" that Anderson acknowledged as important in contemporary feminist ethics. The Conference contributions gave rise to full papers collected in the double issue of Angelaki 25.1-2 (Ed. Pelagia Goulimari, 2020). The first part of the collection comprises Anderson's unpublished works on vulnerability and love edited by her colleagues. The second presents works on the topic by her friends, collaborators and former students, as well as those who engaged with her written output, not knowing her in person.

A brief overview of some selected papers in part two indicates the exceptionally wide range and depth of Anderson's thought displayed through the eyes of the volume contributors. Laurie Anderson Sathe, Pamela's sister, touches upon Anderson's project “Enhancing Capable Life: Transformative Change, Confidence and Creativity" (58-62). Its aim, as the philosopher herself explained, was "to develop an ontology of becoming, with a transformed and transformative conceptual scheme, for creating new concepts to live by (April 2015)." Anderson's unfinished project bespeaks the profundity of her hermeneutic sensibility. Laurie Anderson Sathe accentuates that Anderson "conceived of vulnerability as a capability to enhance our lives in a continual creative process of transformation" (58). It is this transformative dimension of vulnerability, understood in terms of an all embracing mind-body-soul change that Laurie Anderson Sathe finds meaningfully applicable in the context of today's world afflicted with unceasing fear and violence. The import of the formative and trans-formative aspects of human existence-a life-long metanoia - is one of the central themes developed by the iconic figures of philosophical hermeneutics. Undoubtedly, this aspect of Anderson's work on vulnerability is closely akin to Ricour's hermeneutics of the self and Gadamer's hermeneutics of conversation.

In "Pamela Sue Anderson-Witness to the Gospel, Prophet to the Church" (63-67), Susan Durber comments on Anderson's perplexed connection with the church, claiming that her thought is both a challenge to the church and a novel rendition of the church's most profound and pressing teachings. She stresses that Anderson's work encourages women to re-evaluate their life experiences as a legitime wellspring of knowledge, to re-shape their vulnerabilities and to reconfigure love as offering freedom and hope. Morny Joy’s "Pamela Sue Anderson's Journeying 
with Paul Ricœur" (84-96) shows Anderson's engaging with Ricœur's thought, and accentuates the growing import of the philosophical concern with vulnerability in the past ten years, as well as her work on converting the troublesome state of our ignorance of vulnerability into an ethical avowal of it. Paul S. Fiddes (109-25) espouses Anderson's voice on the controversial issues of justice in case of women as victims of abuse, their need for personal and societal integrity and justified anger, as well as the necessity of securing autonomy in expressing themselves. Anderson's reflection on forgiveness, justice and love resonates with Ricour's discussion of love and justice, and the place of love in executing justice. Interestingly, Fiddes theological account of forgiveness intersects with Anderson's insistence on the human struggle with justice involving the promise of a new future.

Another central issue in Anderson's oenore is raised by Dorota Filipczak who responds to the philosopher's addressing of the social mechanisms preventing or censoring feminine self-expressiveness as that of "a knower" (156-64). As Filipczak explains in "The Disavowal of the Female Knower. Reading Literature in the Light of Pamela Sue Anderson's Project on Vulnerability" the female (often feminist) philosopher is mostly perceived through a perspective which is never detached from her physicality. Her femaleness is seen as denigrating her reasoning, or as a disappointment. In the mental constructions controlling cultural and literary discourse, femaleness and intellect are viewed as binarily opposed. Emily Cousens examines Anderson's notion of ethical vulnerability as activating an openness to change, and pursues possibilities that ensue from affirming vulnerability, especially in the context of feminist responses to sexual abuse (165-80). Carla Bagnoli's essay "Love's Luck-Knot” defends Anderson's argumentation for untying love and vulnerability from Western philosophy's myths that insist on their inextricable connection to subjugation, fragility and dependency (195-208). Basing her reflection on the less explored ontological vulnerability in Kant, Bagnoli upholds Anderson's claim of vulnerability's positive value, and argues that love's distinctive dynamism and reciprocity allow for vulnerability not to be seen as an impediment but rather as a fundamental capability that molds human identity and "drives and expands agency, and sustains relations of mutual accountability" (195). Let us conclude this survey with another perspective drawing attention to Kantian legacy in Anderson's thinking. Elaborating Anderson's debate with Kant, Alison Assiter investigates vulnerability's relationship to freedom and autonomy (222-30). She also discusses convincingly the normatively desirable vulnerability (e.g., psychical or corporeal openness to others), and undesirable forms of vulnerability (domestic violence and rape). 


\section{SELF-UNDERSTANDING AND WOMAN AS A KNOWER}

The human capability of love and the corresponding vulnerability are undeniably important facets of Anderson's philosophical reflection. However, it is noticeable that she places greatest emphasis on the situation of a female subject whose intellectual capabilities have been denied by a male subject/s. This stance calls for the consideration of a far more encompassing conceptualization of vulnerability, one which reaches out for an understanding of a human being in his/her entirety. Anderson's overall view of vulnerability (a woman-philosopher stance) as less affective-oriented, more open, and epistemically laden finds its counterpart in the broader landscape of conceptualizing vulnerability. The epistemic and existential standpoint on vulnerability has been commendably expressed thus:

Vulnerability is the very condition of knowledge since it makes us sensitive to all the details that are relevant to our engagement with life: awakening to ourselves. It encompasses transforming the inexplicable into the real fabric of life, a life that can be experienced by everybody who

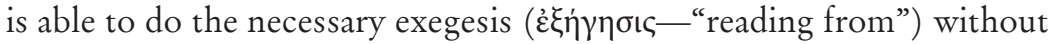
falling prey to imposing one's own pre-conceived ideas of the projected

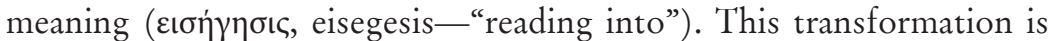
a long and laborious path to the discovery of meaning. It is an exercise in allowing that which needs to be interpreted to speak to the interpreter. (Wierciński, "Phronetic Education" 8)

Considering vulnerability as a pathway to discovering our true selves in the complex and changing reality of life draws us nearer to a comprehension of Anderson's insistence on the distinctly feminine capability and her loss of confidence. The revalidation of the weightiness of the female voice as expressive of her idiosyncratic thinking involves openness on the part of both sexes: male and female. Instead of fleeing from what seems to be at first too perplexing, too discomfiting, or even endangering in a relationship oriented toward mutual trust and enrichment in particular societal constructions, gender coexistence/cooperation requires an effort to disavow one's pre-conceptions of life. It calls for a resignation from the safeguarding of one's borders and from upkeeping one's defenses. This is a situation of vulnerability which requires maturity and wisdom. It is the recognition of the Other's valuable presence and voice that enables us to surmount excessive vulnerability and opens a genuine path of selfunderstanding. Recognition of oneself, of the Other, and of oneself through the Other are crucial for our development as human subjects. Ricour asserts: 
Recognition is a structure of the self, reflecting on the movement that carries self-esteem toward solicitude and solicitude to justice. Recognition introduces the dyad and plurality into the very constitution of the self. Reciprocity in friendship and proportional equality in justice, when they are reflected in self-consciousness, make self-esteem a figure of recognition. (Oneself as Another 296)

The constitution of the female self demands a renewed recognition of her capability. This is one of the central concerns of contemporary feminist ethics. Anderson's critique of the patriarchal configuring of the Biblical story of original sin can be viewed as representative of the important response that today's feminist ethics gives to the imposed intellectual disequilibrium between genders. Her invaluable contribution to the feminist hermeneutic reconfiguring of the Bible messages can be seen as drawing attention to "male self-projection implicit in traditional theism," but also as offering "a way to transform biased beliefs so as to include the needs of women and nonprivileged men" (Filipczak 15).

The Bible excerpt on original sin can be re-read hermeneutically to unveil Eve as a powerfully capable subject. She is capable of choosing. If demeaned later (and this relates to Adam too), it is only because of her primordial capability of choosing. Even if the wrong choice infuses her with a sense of being less capable, Eve testifies to God's creation of her as a free human being. In not choosing rightly, she is still a capable subject. The outcome of the transgression of God's law is acute for both the female and male capability. We can talk about a wounded, or even shattered capability, regardless of gender. The beauty of creation was desecrated, and this is what needs to be restored. The guilt lies equally with Adam and Eve, and affects them both; it only has a different form. The form, however, is of secondary importance because it is the pre-given capability that asks to be reinstated.

Undeniably, the rehabilitation of the feminine voice is what underpins Anderson's feminist philosophy of religion. Although this article does not aim to focus on her accomplishments in this field, it is worth mentioning the areas of research in which the female feminist philosopher finds inimitable ways to raise topical queries. In New Topics in Feminist Philosophy of Religion, Contestations and Transcendence Incarnate (2010), Anderson claims that:

Feminist "philosophers" of religion exist; but due to social and institutional resistance, many of these feminists work for change at the margins of philosophy, in interdisciplinary locations bridging philosophy and theology, philosophy and literature, philosophy and women studies, philosophy and religious studies, philosophy and gender theory, philosophy and politics, philosophy and the social 
sciences (including anthropology), and philosophy and education (e.g., critical pedagogy). (xii)

The feminine voice in the domain of the philosophy of religion, located at the junctions of various disciplines, calls to be fore-fronted. It also expresses the necessity of promoting the distinct feminine capability.

Although, as mentioned earlier, Anderson does not follow the precepts of Kristevan psycho-linguistics in resolving the question of the loss of the specifically feminine capability, it is vital to notice that she acknowledges Kristeva's insight into the situation of a female intellectual as that of an exile. Creating from a perspective of the periphery incites a specific kind of input into feminist ethics. Anderson writes:

What more precisely, does marginality contribute to either the knowledge or the transformation of the subject and its other? Kristevan psycholinguistics may not have an explicit, epistemological answer. Yet at the very least Kristeva follows the post-Hegelian philosophy in implying that marginality can offer a new standpoint on good and evilfor an "ethics of knowledge." ("On the Boundaries" 42)

The position of an intellectual dissident enables to make a real contact with the empowerment of thinking through thinking-the-difference. The woman subject uncovers in her denigrated femaleness a new impulse to reconsider the expected balance between the sexes, and to oppose the imposed reductionist approach in exposing her intellectual strengths and gifts. As Filipczak explicates after Anderson, this involves women reinventing themselves as "other," prompted by the "paradoxes and transformations in their emotional life, religious experience and creativity" (21) (see Anderson, A Feminist Philosophy 19).

Discussing the marginalization of the feminine voice in philosophy as interwoven with the question of lost confidence, Anderson draws our attention to an important aspect of disregarding the feminine input into philosophical thought. In "Silencing and Speaker Vulnerability: Undoing an Oppressive Form of (Wilful) Ignorance," which could be treated as her manifesto of the need to re-empower feminine thinking, she argues that "[s]ilencing exploits vulnerability; and speaker vulnerability is an exposure to either violence or affection, in its dependence on an audience." Examining the ways in which contemporary conceptualizations of vulnerability reduce it to a susceptibility to violence, and ignore the unthought - an openness to affection, she makes the following claim:

A wilful ignorance of vulnerability develops not as a lack of knowledge, but its disavowal—on which various forms of oppression are built. 
An active disavowal of thinking (the unthought) is the other side of a striving for invulnerability; and this striving is encouraged by a social world which remains ignorant of its own wounding, as well as its own potential for ethical relations in vulnerability. ("Speaker Vulnerability")

Anderson's capacity to see the other side of the problem of vulnerability, which, at the same time, amounts to her piercing through the state of invulnerability, attests to realizing the ethos of thinking-the-difference par excellence. Thinking-the-difference results in the possibility of subverting the pejorative side of the vulnerability issue and seeing the potentialities that lie on the reverse side as brought to light.

Anderson's deliberation on being a knower, being recognized as a knower, and woman as a knower is an interesting contribution to our understanding not only of the psycho-dynamics of speaking, but is one of the ways of rendering the import of the epistemic autonomy. She says:

every speaker-whatever their sex or gender-is vulnerable precisely because they are also dependent on an audience not only to hear them, but to recognize them as a knower. So, to repeat, a philosopher is open to not having her speaker's needs met; this means vulnerability. Silencing is the risk a speaker runs, since an audience might not hear her or recognize her as a knower. (Anderson, "Speaker Vulnerability")

Highlighting the importance of transforming our ignorance of vulnerability into a distinctively ethical assertion of it (Anderson, "Speaker Vulnerability") leads us to the very crux of her standpoint, which is a rethought understanding of a human being as a vulnerable and capable being.

\section{CONCLUDING REMARKS}

The problematic rendered in the above reflection on Anderson's philosophy of capability and vulnerability, with the inclusion of references to some selected papers in the recent volume on vulnerability and love, does not exhaust the conversation with her philosophical thought continued posthumously. The essay's aim was to show that thinking with Anderson is undoubtedly an enriching journey into the highly nuanced paths of thematizing capability and vulnerability. Her hermeneutic approach encompasses those forays which are easily overlooked in less comprehensive attempts to do justice to the versatility of the capability/ vulnerability quandary. We are indebted to her for her insightful appropriations of Ricœur's philosophy and the acquainting of a wider readership with his hermeneutics of the self (especially in the United 
Kingdom's academic milieu), and also for her original, feminist thought that allows for engagement with the otherwise neglected, marginalized, or even silenced areas of what it means to be a human being, also a human being as homo religiosus.

It is vital to emphasize that Anderson's oewvre (approached here through the topic of her assertions on capability and vulnerability) is not just most influential in a dialogue with the orthodoxies of traditional theism opened by the feminist philosophy of religion, but also impacts contemporary, multidisciplinary research in the Humanities. Anderson proves that being deaf to the idiosyncrasies of feminine thinking in the humanistic research substantially delimits our understanding of the crucial facets of human existential situation as a capable and vulnerable subject. Expanding our scope of thinking, Anderson's is a resounding voice which not only identifies the masculine prejudice against the significance and value of feminist thought, but inspires women and men alike to engage in blossoming as embodied, gendered subjects, awakened to cooperate with, rather than oppose, each other. Her feminist writing can also be viewed as perfectly expressing women's need to liberate themselves from the constraints of being defined by assumed feminine emotionality. Anderson's continuous insistence on including women as legitimate subjects in philosophy, and the philosophy of religion in particular, testifies to her ambitious project of upgrading an autonomous feminine voice in its expressiveness of regained confidence in her distinct female capability.

\section{Works CiTED}

Anderson, Pamela Sue. A Feminist Philosophy of Religion. Oxford: Blackwell, 1998. Print.

Anderson, Pamela Sue."Engaging the 'Forbidden Texts' of Philosophy. Pamela Sue Anderson Talks to Alison Jasper." Text Matters 1 (2011): 312-28. Print. https://doi.org/10.2478/v10231-011-0021-8

Anderson, Pamela Sue. Introduction. New Topics in Feminist Philosophy of Religion: Contestations and Transcendence Incarnate. Dordrecht: Springer, 2010. Print. xi-xiv. https://doi.org/10.1007/978-1-4020-6833-1

Anderson, PamelaSue."Lost Confidence and Human Capability: A Hermeneutic Phenomenology Of the Gendered, yet Capable Subject." Text Matters 4 (2014): 31-52. Print. https://doi.org/10.2478/texmat-2014-0003

Anderson, Pamela Sue. "Michèle Le Douff's 'Primal Scene': Prohibition and Confidence in the Education of a Woman.” Text Matters 1 (2011): 11-26. Print. https://doi.org/10.2478/v10231-011-0002-y 
Anderson, Pamela Sue. "On the Boundaries of Intellectual Thought in Late Twentieth-Century Europe." Dissolving the Boundaries. Ed. Dorota Filipczak. Łódź: U of Łódź P, 2001. 35-49. Print.

Anderson, Pamela Sue. "Silencing and Speaker Vulnerability: Undoing an Oppressive Form of (Wilful) Ignorance." Womenimparenthesis.co.uk. (In Parenthesis) 25 Mar. 2016. Web. 2 Jan. 2020.

Chiari, Gabriele. "Recognition in Kelly's Sketchy View of Personal Identity Construction." Personal Construct Psychology at 60: Papers from the $21^{\text {st }}$ International Congress. Ed. David Winter, Peter Cummins, Harry Procter and Nick Reed. Newcastle upon Tyne: Cambridge Scholars, 2017. 54-68. Print.

Crosby, John F. The Personalism of John Henry Nerman. Washington, DC: The Catholic U of America P, 2014. Print. https://doi.org/10.2307/j. ctt1287bv7

Filipczak, Dorota. "Unheroic Heroines." The Portrayal of Women in the Writings of Margaret Laurence. Łódź: U of Łódź P, 2007. Print.

Gadamer, Hans-Georg. Truth and Method. Trans. Joel Weinsheimer and Donald G. Marshall. New York: Continuum, 2006. Print.

Goulimari, Pelagia, ed. Angelaki. Journal of the Theoretical Humanities. Love and Vulnerability: Thinking with Pamela Sue Anderson 25.1-2 (Feb. 2020). Print. https://doi.org/10.1080/0969725X.2020.171776

Helenius, Timo. "The Will, the Body and Sexuality. Ricœur's Hermeneutic Phenomenology of 'Being Willing and Able." Paul Ricoeur in the Age of Hermeneutical Reason: Poetics, Praxis, and Critique. Ed. Roger W. H. Savage. London: Lexington, 2015. 191-210. Print.

Kearney, Richard. "Ricœur's Wager of Flesh: Between Phenomenology and Hermeneutics." Paul Ricceur in the Age of Hermenentical Reason: Poetics, Praxis, and Critique. Ed. Roger W. H. Savage. London: Lexington, 2015. 179-90. Print.

Le Dœuff, Michèle. Hipparchia's Choice: An Essay Concerning Women, Philosophy, etc. Trans. Trista Selous. New York: Columbia UP, 2006. Print. https://doi.org/10.1111/j.1468-0149.1993.tb00757.x

Love and Vulnerability: Reflections on the Work of Pamela Sue Anderson Conference. Oxford University 16-18 March 2018. Philosophy.ox.ac.uk. Faculty of Philosophy, University of Oxford. Web. 30 Dec. 2019.

Merleau-Ponty, Maurice. Phenomenology of Perception. Trans. Colin Smith. London: Routledge Classics, 2002. Print. https://doi. org/10.4324/9780203994610

Nussbaum, Martha C. Love's Knowledge: Essays on Philosophy and Literature. New York: Oxford UP, 1992. Print.

Ricour, Paul. "Autonomy and Vulnerability." Reflections on the Just. Trans. David Pellauer. Chicago: U of Chicago P, 2007. 72-90. Print. 
Ricœur, Paul. Freedom and Nature: The Voluntary and the Involuntary. Trans. Erazim V. Kohak. Evanston: Northwestern UP, 1966. Print.

Ricœur, Paul. Oneself as Another. Trans. Kathleen Blamey. Chicago: U of Chicago P, 1992. Print. https://doi.org/10.1017/S0034412500023003 Ricœur, Paul. The Conflict of Interpretations: Essays in Hermenentics. Ed. Don Ihde. Trans. Willis Domingo et al. Evanston, IL: Northwestern UP, 1974. Print.

Ricour, Paul. The Course of Recognition. Trans. David Pellauer. Cambridge, MA: Harvard UP, 2005. Print.

Wierciński, Andrzej. Existentia Hermeneutica. Understanding as the Mode of Being in the World. Zürich: LIT Verlag, 2019. Print.

Wierciński, Andrzej. Hermeneutics of Education: Exploring and Experiencing the Unpredictability of Education. Zürich: LIT Verlag, 2019. Print.

Wierciński, Andrzej. "Phronetic Education to Integrity. Capability, Courage, and Passion for Thinking." Phainomena. Journal of Phenomenology and Hermeneutics 28.110-111 (2019): 5-15. Print.

Małgorzata Hołda, PhD in British literature (Nicolaus Copernicus University in Torun 2006), $\mathrm{PhD}$ in philosophy with distinction for dissertation: Paul Ricour's Concept of Subjectivity and the Postmodern Claim of the Death of the Subject (The Pontifical University of John Paul II in Krakow), published with Ignatianum University Press, 2018. She has been Junior Associate Fellow of the International Institute for Hermeneutics in Freiburg since 2014. She conducts interdisciplinary research in Anglophone literature and philosophy, exploring topics within modern and postmodern novel, philological and philosophical hermeneutics, phenomenology and postmodern philosophy. Her most recent research concerns Virginia Woolf's and Hans-Georg Gadamer's hermeneutics of the beautiful, as well as Paul Ricœur's hermeneutics of l'bomme capable, and subjectivity. Her publications foster an understanding of hermeneutics as a mode of being. ORCID: 0000-0003-3772-6297 malgorzata.holda@uni . Iodz.pl 